\title{
Extracts of Clove (Syzygium aromaticum) Potentiate FMSP-Nanoparticles Induced Cell Death in MCF-7 Cells
}

\author{
Firdos Alam Khan $\mathbb{D}^{1},{ }^{1}$ Sultan Akhtar, ${ }^{2}$ Dana Almohazey, \\ Munthar Alomari, ${ }^{1}$ and Sarah Ameen Almofty ${ }^{1}$ \\ ${ }^{1}$ Department of Stem Cell Biology, Institute for Research and Medical Consultations, Imam Abdulrahman Bin Faisal University, \\ Post Box No. 1982, Dammam 31441, Saudi Arabia \\ ${ }^{2}$ Department of Biophysics, Institute for Research and Medical Consultations, Imam Abdulrahman Bin Faisal University, \\ Post Box No. 1982, Dammam 31441, Saudi Arabia
}

Correspondence should be addressed to Firdos Alam Khan; fakhan@iau.edu.sa

Received 26 April 2018; Revised 19 July 2018; Accepted 1 August 2018; Published 23 August 2018

Academic Editor: Carlo Galli

Copyright (C) 2018 Firdos Alam Khan et al. This is an open access article distributed under the Creative Commons Attribution License, which permits unrestricted use, distribution, and reproduction in any medium, provided the original work is properly cited.

Both nanoparticles and cloves (Syzygium aromaticum) possess anticancer properties, but they do not elicit a significant response on cancer cells when treated alone. In the present study, we have tested fluorescent magnetic submicronic polymer nanoparticles (FMSP-nanoparticles) in combination with crude clove extracts on human breast cancer cells (MCF-7) to examine whether the combination approach enhance the cancer cell death. The MCF-7 cells were treated with different concentrations $(1.25 \mu \mathrm{g} / \mathrm{mL}$, $12.5 \mu \mathrm{g} / \mathrm{mL}, 50 \mu \mathrm{g} / \mathrm{mL}, 75 \mu \mathrm{g} / \mathrm{mL}$, and $100 \mu \mathrm{g} / \mathrm{mL}$ ) of FMSP-nanoparticles alone and in combination with $50 \mu \mathrm{g} / \mathrm{mL} \mathrm{crude}$ clove extracts. The effects of FMSP-nanoparticles alone and combined with clove extracts were observed after $24 \mathrm{hrs}$ and $48 \mathrm{hrs}$ intervals. The response of FMSP-nanoparticles-treated cells was evaluated by Trypan Blue, 4',6-diamidino-2-phenylindole (DAPI), and 3(4,5-dimethylthiazol-2-yl)-2,5-diphenyltetrazolium bromide (MTT) assays, respectively. We have demonstrated that cancer cell viability was decreased to $55.40 \%$ when treated with FMSP-nanoparticles alone, whereas when cancer cells were treated with FMSP-nanoparticles along with crude clove extracts, the cell viability was drastically decreased to $8.50 \%$. Both morphological and quantitative data suggest that the combination of FMSP-nanoparticles plus crude clove extracts are more effective in treating cancer cells and we suggest that the combination treatment of nanoparticles along with clove extracts hold a great promise for the cancer treatments.

\section{Background}

Breast cancer is one of the leading causes of death among women [1] and all available treatments such as chemotherapy, radiotherapy, hyperthermia, and gene therapy [2-6] do not completely control the progression of the cancer, carrying lots of side effects. Another limiting factor of current therapy is that it is based on single-mode treatment. Over the past few years, combination therapy has been successfully employed where chemotherapy is combined with radiotherapy or biotherapy combined with hyperthermia [7, 8]. In recent years, nanomedicines have been approved by the US Food and Drug Administration (FDA) for human use, and some others are undergoing clinical trials [9]. Nanoparticles have shown some exciting results in cancer cells because of their precise targeting, biocompatibility, bioavailability, and multifunctional capabilities [10-12]. Several studies have demonstrated that nanoparticles possessed anticancer properties when tested under in vitro and in vivo conditions [1318] (Wang et al., 2009) [19-23]. Nanoparticles do carry some side effects or toxic effects when tested on high concentrations, but this problem can be solved if nanoparticles are treated along with other plant extracts. For several years, combination therapy has been among the most promising developments for obtaining high therapeutic effects with very low toxicity [24]. One of the important strategies to increase the efficacy of nanoparticles is by combining low doses of nanoparticles with either drug or plant extracts 
[24, 25]. Moreover, combination therapy plays a major role in minimizing drug resistance, undesired side effects, and chemoresistance, which are critical problems in cancer therapy [26]. In the present study, we have studied the effect of fluorescent magnetic submicronic polymer nanoparticles (FMSP-nanoparticles) alone and in combination with clove extracts on human breast cancer cells (MCF-7). The main reason to use clove extracts along with nanoparticles was to examine whether clove extracts enhance the nanoparticles impact on cancer cells growth and progression. There are several reports which have demonstrated that clove extracts have strong anticancer properties [27-30]. We have used different concentrations of FMSP-nanoparticles alone and in combination with clove extracts at different time intervals ( $24 \mathrm{hr}$ and $48 \mathrm{hr}$ ) and evaluated their cytotoxic effects by both morphometric and quantitative methods.

\section{Materials and Methods}

2.1. Synthesis and Characterization of FMSP-Nanoparticles. FMSP-nanoparticles were prepared according to a previously described [31]. In brief, an organic ferrofluid which composed of iron oxide nanoparticles was stabilized in octane which was surrounded by oleic acid. First deionized water was added to the anionic magnetic emulsion and the mixture was homogenized. After that, the supernatant was detached, and the magnetic droplets were then added in deionized water. Then deionized water was added and polyethyleneimine solution was added and, after 15 mins of continuous stirring, the magnetic droplets were washed with deionized water. The amount of polyethyleneimine was adsorbed onto the magnetic droplets and was construed by using specific amine titration. The obtained fluorescent magnetic nanoparticles were then quantified by using a fluorescence spectrophotometer (LS-50 System, Perkin Elmer). Characterization of FMSP-nanoparticles was performed according to a previously described method [31]. In brief, the structure and morphology of FMSP-Nanoparticles were examined by scanning electron microscopy (SEM) (FEI, INSPECT S50, Check Republic), and the size of fluorescent submicron magnetic nanoparticle was measured by transmission electron microscopy (TEM) (FEI, MORGAGNE.68, Check Republic) respectively.

2.2. Extraction of Clove. Whole cloves were purchased from local markets in Dammam, Saudi Arabia, which weree manufactured by Muntazah Food Industries, Saudi Arabia. Clove was dried and ground into fine powder and fine powder of clove (4.0 grams) was dissolved in $25 \mathrm{~mL}$ of $70 \%$ ethanol. Dissolved mixture was then processed under sonicator $(50$ amplitude) for 10 minutes. The mixture was kept in the dark for 24 hours at room temperature, wrapped with aluminium foil to avoid evaporation and exposure to sunlight was avoided. The mixture was filtered through Whatman no. 1 filter paper and kept it in incubator at $37^{\circ} \mathrm{C}$ till ethanol had completely evaporated from mixtures. After that ethanolic clove samples were dissolved in phosphate buffer saline, $\mathrm{pH}$ 7.4, and processed for autoclave for 20 minutes.
2.3. Cell Culture and Treatments. MCF-7 is a breast cancer cell line with passage number 46 obtained from Dr. Khaldoon M. Alsamman, Clinical Laboratory Science, College of Applied Medical Science, Imam Abdulrahman Bin Faisal University, Dammam, Saudi Arabia. MCF-7 cells were cultured in T25 flask containing the DMEM media containing L-glutamine, $10 \% \mathrm{FBS}$, selenium chloride, $120 \mathrm{U} / \mathrm{mL}$ penicillin, and $120 \mu \mathrm{g} / \mathrm{mL}$ streptomycin at $37^{\circ}$ Celsius in $5 \%$ $\mathrm{CO}_{2}$ incubator (Heracell 150i, Thermoscientific). The cells were then seeded into 6-well, 96-well cell culture plates, and 8-chamber slides to be used for FMSP-nanoparticles and clove extract treatments. The cells with more than $80 \%$ confluence were used for the treatments. Before treatments, both FMSP-nanoparticles and clove extracts were autoclaved for $30 \mathrm{~min}$ to remove the contamination from the sample. The cancer cells were treated to different concentrations of FMSP-nanoparticles $(1.25 \mu \mathrm{g} / \mathrm{mL}, 12.5 \mu \mathrm{g} / \mathrm{mL}$, and $50 \mu \mathrm{g} / \mathrm{mL}$; $75 \mu \mathrm{g} / \mathrm{mL} ; 100 \mu \mathrm{g} / \mathrm{mL}$ ) alone and in combination with clove extracts $(50 \mu \mathrm{g} / \mathrm{mL})$. The treated cells were analyzed after $24 \mathrm{hrs}$ and $48 \mathrm{hrs}$ intervals. For all the treatments, triplicate samples were taken for statistical calculations.

2.4. Cell Morphology. At the end of each treatment $(24 \mathrm{hrs}$ and $48 \mathrm{hrs}$ ), the MCF-7 cells from different treatments were removed from the incubator and were observed under an inverted microscope (TS100F Eclipse, Nikon) equipped with a digital camera. Each sample was observed under 10x, 20x, and 40x magnification and the cell morphology of control samples and treated samples were observed, and their images were recorded for the analysis.

2.5. Trypan Blue Staining. Trypan blue staining was performed to quantify the number of MCF-7 dead cells due to nanoparticle or nanoparticle + clove extract treatments. The cells were first washed with phosphate buffered saline (PBS) and then stained with Trypan blue (MPXX Biochemicals, Germany) prepared in a $0.4 \%$ solution in PBS. After 20 mins, the samples were processed for manual counting using a haematocytometer under an inverted microscope (TS100F Eclipse, Nikon). The difference between live cells and dead cells (blue colour) was calculated and compared in both FMSP-nanoparticles and FMSP-nanoparticles + clove extract treated groups, respectively.

2.6. MTT Assay. The MCF-7 cells were first cultured in the media containing DMEM supplemented with $10 \%$ FBS and $1 \%$ penicillin $(100 \mathrm{IU} / \mathrm{mL})$ and streptomycin $(100 \mu \mathrm{g} / \mathrm{mL})$ in the $\mathrm{CO}_{2}$ incubator with $37^{\circ} \mathrm{Celsius}$ and $5 \% \mathrm{CO}_{2}$ condition. Cells with $6 \times 10^{4}$ cells $/ \mathrm{mL}$ concentration were seeded in 96well cell culture plates and incubated in $\mathrm{CO}_{2}$ incubator. Upon reaching $80 \%$ confluency, cancer cells were treated to different concentrations of FMSP-nanoparticles $(1.25 \mu \mathrm{g} / \mathrm{mL}$, $12.5 \mu \mathrm{g} / \mathrm{mL}$, and $50 \mu \mathrm{g} / \mathrm{mL}$ ) alone and in combination with clove extracts $(1 \mu \mathrm{g} / \mathrm{mL}, 20 \mu \mathrm{g} / \mathrm{mL}, 30 \mu \mathrm{g} / \mathrm{mL})$. In control group, no FMSP-nanoparticles or clove extracts were not added. After $48 \mathrm{hr}$ treatment, $20 \mu \mathrm{L}$ of MTT $(5 \mathrm{mg} / \mathrm{mL})$ was added to each well and incubated for $4 \mathrm{hr}$. The media were changed with DMSO and each well was measured by using 


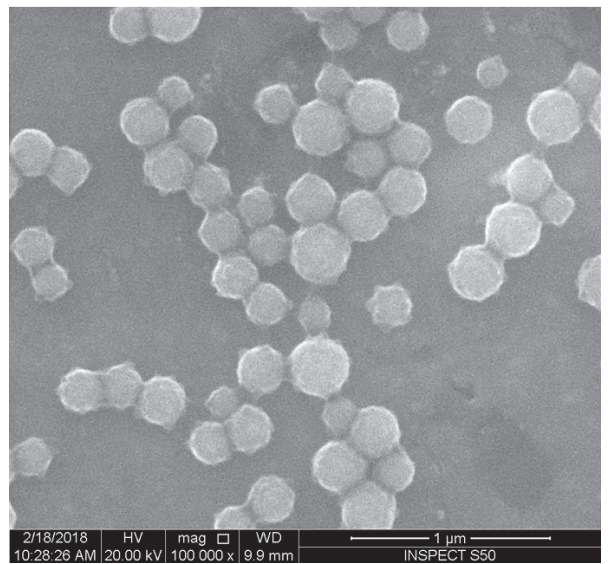

(a)

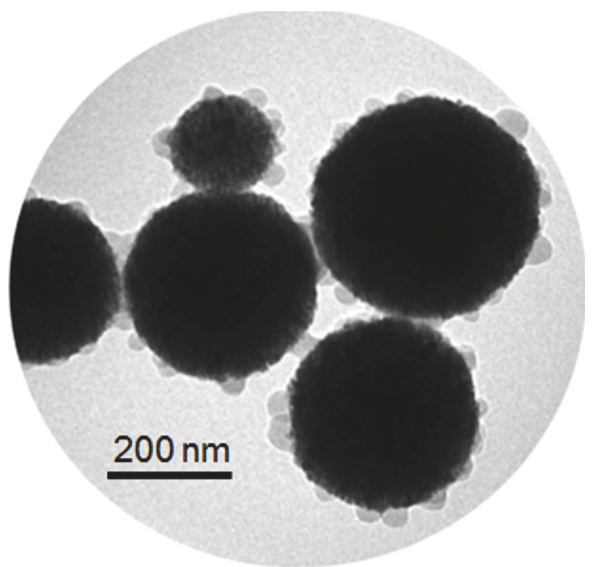

(b)

FIGURE 1: (a) Structure of fluorescent magnetic submicronic polymer FMSP-nanoparticles through Scanning Electron Microscope (SEM) with $100,000 \mathrm{x}$ magnification. (b) Structure of fluorescent magnetic submicronic polymer FMSP-nanoparticles through Transmission Electron Microscope (TEM) with 70,000 x magnification.

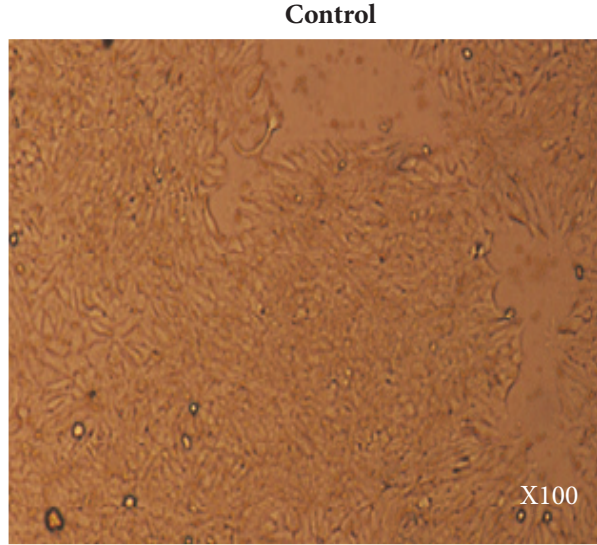

(a)

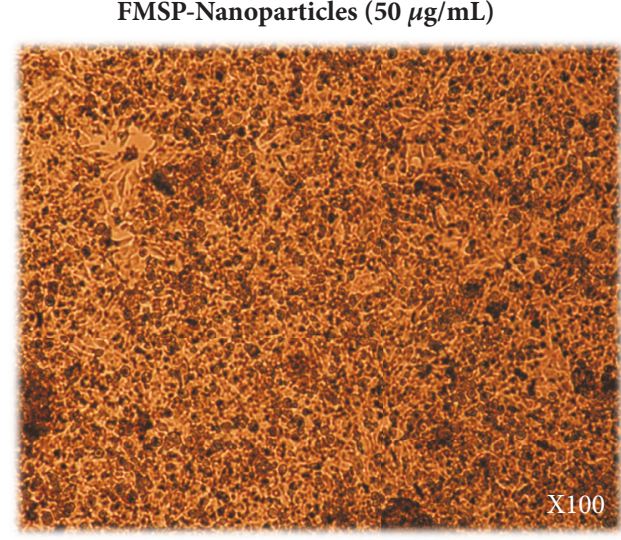

(b)

FMSP-Nanoparticles $(50 \mu \mathrm{g} / \mathrm{mL})+$ Clove extract

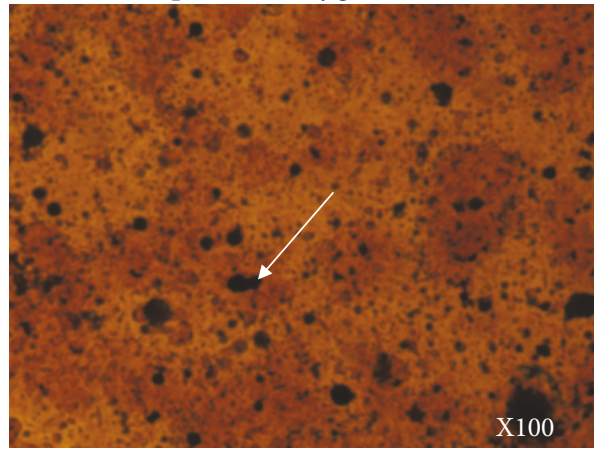

(c)

FIGURE 2: Cell morphology after treatment of FMSP-Nanoparticles alone: the MCF-7 cells were analyzed 48 hrs posttreatment. Figure (a) is control; Figure (b) is treated with FMSP-nanoparticles $(50 \mu \mathrm{g} / \mathrm{mL})$; and Figure (c) is treated with FMSP-nanoparticles $(50 \mu \mathrm{g} / \mathrm{mL})+\mathrm{clove}$ extracts $(100 \mu \mathrm{g} / \mathrm{mL})$. Arrows indicate cell dead cell debris. $100 \mathrm{x}$ magnifications. 


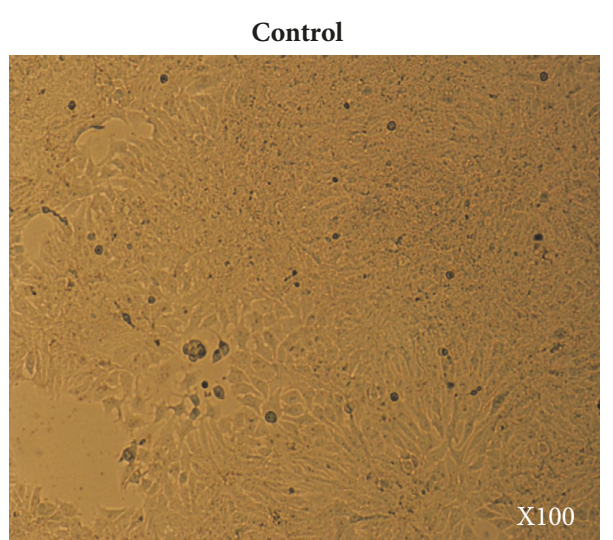

(a)

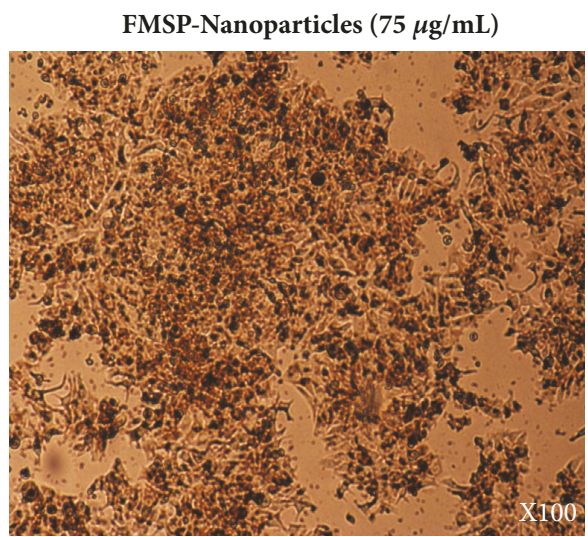

(b)

FMSP-Nanoparticles $(75 \mu \mathrm{g} / \mathrm{mL})+$ Clove extract

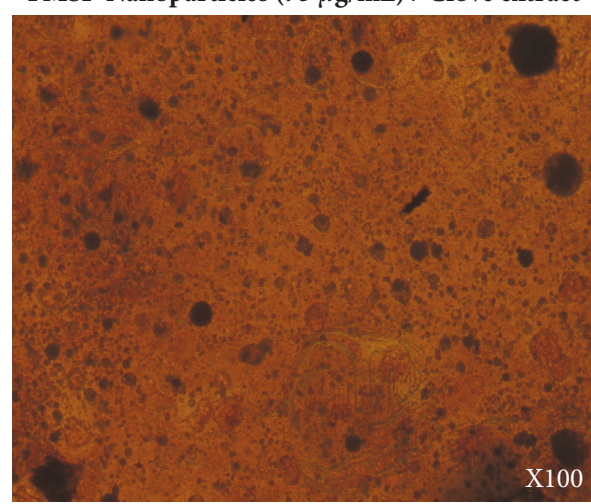

(c)

FIgURE 3: Cell morphology: the MCF-7 cells were analyzed $48 \mathrm{hrs}$ posttreatment. Figure (a) is control; Figure (b) is treated with FMSPnanoparticles $(75 \mu \mathrm{g} / \mathrm{mL})$; Figure (c) is treated with FMSP-nanoparticles $(75 \mu \mathrm{g} / \mathrm{mL})+$ clove extracts $(100 \mu \mathrm{g} / \mathrm{mL})$. Arrows indicate cell dead cell debris. $100 \mathrm{X}$ magnifications.

an ELISA plate reader (Synergy NEO2, Biotek Instruments, Winooski, VT, USA) at $570 \mathrm{~nm}$ wavelength. Percentage (\%) of cell viability (\%) was calculated as per the given formula:

\section{$\%$ of Cell viability}

$$
\begin{aligned}
= & \frac{\text { Optical density of Nanoparticles-treated cells }}{\text { Optical density of control cells }} \\
& \times 100
\end{aligned}
$$

2.7. Statistical Analysis. All data were presented as mean \pm standard deviation from triplicate experiments. The difference between control and FMSP-nanoparticles was evaluated by Student's $t$-test where p-values were calculated by Student's $t$-test $\left({ }^{*} \mathrm{p}<0.05,{ }^{* *} \mathrm{p}<0.01\right.$ and $\left.{ }^{* * *} \mathrm{p}<0.001\right)$.

\section{Results}

3.1. Characterization of FMSP-Nanoparticles. The structure of FMSP-nanoparticles was determined by both SEM and TEM analysis. The nanoparticles appeared to be crystallized, and spherical in shape (Figure 1(a)) and TEM analysis revealed nanoparticles have an average diameter of $100 \mathrm{~nm}$ to $300 \mathrm{~nm}$ (Figure 1(b)).

3.2. FMSP-Nanoparticles Inhibits Cell Viability. With a view to check the impact of FMSP-nanoparticles alone on cancer cells, we have evaluated the treated cells both morphologically and quantitatively. We found that FMSPnanoparticles-treated cells showed dose-dependent response. The lower dose $(1.25 \mu \mathrm{g} / \mathrm{mL})$ has not significantly affected the cell viability compared to control group (Figure 6), whereas the dosages of $(12.5 \mu \mathrm{g} / \mathrm{mL}, 50 \mu \mathrm{g} / \mathrm{mL}, 75 \mu \mathrm{g} / \mathrm{mL}$, and $100 \mu \mathrm{g} / \mathrm{mL}$ ) caused dose-dependent decreased in the cell viability $(86.14 \%, 77.54 \%, 64.00 \%$, and $55.40 \%)$, respectively (Figure 6). We have also examined the cell morphology of FMSP-nanoparticles-treated cancer cells under microscope. Treated cells were observed in 100x, 200x, and 400x magnifications to evaluate morphological changes in the nanoparticle-treated cells. The morphology of control group cells remained normal and healthy during the testing phase (Figures 2(a), 3(a), and 4(a)). The dose of $1.25 \mu \mathrm{g} / \mathrm{mL}$ did not show any morphological changes, whereas the dosages of $12.5 \mu \mathrm{g} / \mathrm{mL}, 50 \mu \mathrm{g} / \mathrm{mL}$, and $75 \mu \mathrm{g} / \mathrm{mL}$ showed strong morphological changes in the cell structure, cell membrane, and 


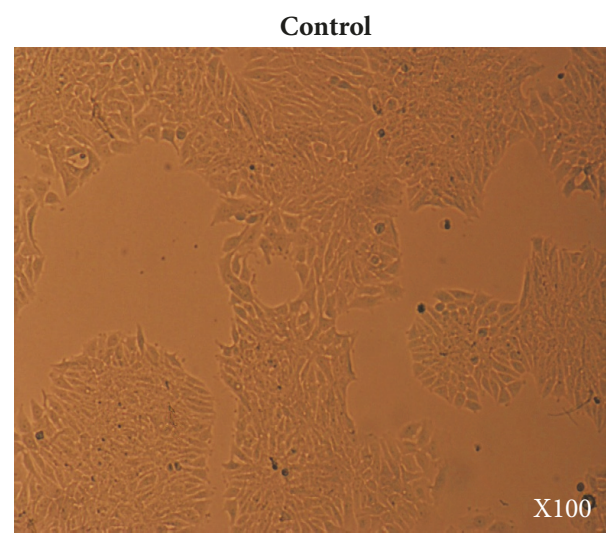

(a)

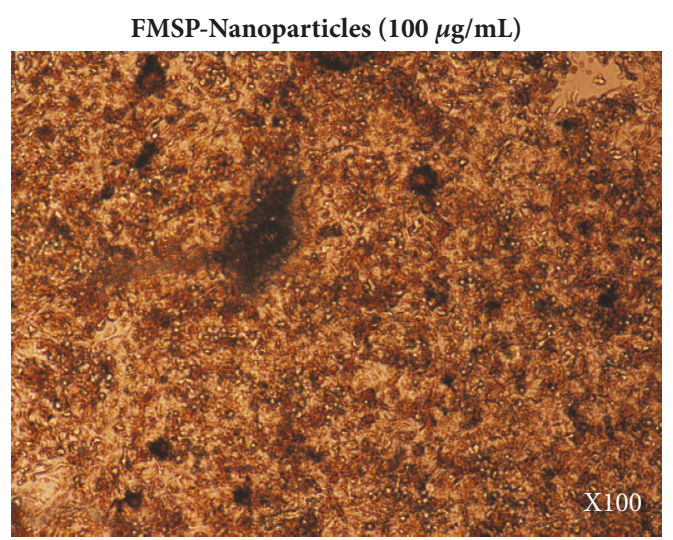

(b)

FMSP-Nanoparticles $(100 \mu \mathrm{g} / \mathrm{mL})+$ Clove extract

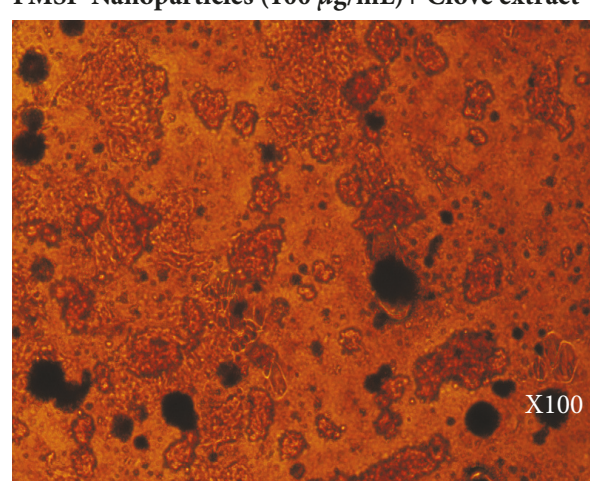

(c)

FIgURE 4: Cell morphology: the MCF-7 cells were analyzed $48 \mathrm{hrs}$ posttreatment. Figure (a) is control; Figure (b) is treated with FMSPnanoparticles $(100 \mu \mathrm{g} / \mathrm{mL})$; Figure $(\mathrm{c})$ is treated with FMSP-nanoparticles $(100 \mu \mathrm{g} / \mathrm{mL})+$ clove extracts $(100 \mu \mathrm{g} / \mathrm{mL})$. Arrows indicate cell dead cell debris. $100 \mathrm{X}$ magnifications.

cell viability (Figures 2(b), 3(b), and 4(b)). There was an indication of nuclear disintegration, nuclear condensation, and nuclear fragmentation after the treatments. Also, few cells were found to be floated in the media (Figure 3(b)). We also observed many dead cells and their debris in the culture media (Figure 4(b)).

3.3. Clove Extracts Potentiate FMSP-Nanoparticles Inhibition on Cell Viability. We have examined the combined effect of FMSP-nanoparticles in combination with clove extracts alone on cancer cells using both morphometric and quantitative analyses. Like FMSP-nanoparticles alone treated cells, FMSP-nanoparticles+clove extracts also showed dose-dependent response. The lower dose of nanoparticles $(1.25 \mu \mathrm{g} / \mathrm{mL})+$ clove extracts $(1.25 \mu \mathrm{g} / \mathrm{mL})$ caused decreases in cell viability to $75.70 \%$ with compared to control group (Figure 6), whereas the dosages of $(12.5 \mu \mathrm{g} / \mathrm{mL}, 50 \mu \mathrm{g} / \mathrm{mL}$, $75 \mu \mathrm{g} / \mathrm{mL}, 100 \mu \mathrm{g} / \mathrm{mL}$ ) caused dose-dependent decreased in the cell viability $(55.35 \%, 30.85 \%, 20.40 \%$, and $8.50 \%)$, respectively (Figure 6). With a view to understand the impact of FMSP-nanoparticles along with clove extracts on cancer cell structure and morphology, we have examined the cell morphology under microscope using 100x, 200x, and 400x magnifications. The morphology of control group cells remained normal (Figures 2(a), 3(a), and 4(a)) and healthy during the testing phase. The dose of nanoparticles $1.25 \mu \mathrm{g} / \mathrm{mL}$ and $12.5 \mu \mathrm{g} / \mathrm{mL}$ with $100 \mu \mathrm{g} / \mathrm{mL}$ of clove extracts showed minor morphological changes in cell structure, whereas the dosages of $50 \mu \mathrm{g} / \mathrm{mL}, 75 \mu \mathrm{g} / \mathrm{mL}$, and $100 \mu \mathrm{g} / \mathrm{mL}$ along with $100 \mu \mathrm{g} / \mathrm{mL}$ of clove extracts showed strong morphological changes in the cell structure, cell membrane, and cell viability (Figures 2(c), 3(c), and 4(c)). Most striking observations were complete losses of cells and their organelles (Figure 4(c)). We also observed many dead cells and their debris in the culture media (Figure 4(c)). Percentage of cell viability of FMSPnanoparticles + clove extracts treated cells was significantly lower than FMSP-nanoparticles alone treated cells (Figure 6).

3.4. FMSP-Nanoparticles Induced Apoptosis in MCF-7 Cells. With a view to understand the cause of cell death, cancer cells treated with the combined effect of FMSP-nanoparticles and clove extracts were stained with DAPI $48 \mathrm{hrs}$ posttreatment. We have found that control group cells showed the normal cell profile and DAPI-positive cells (Figure 5(a)), whereas doses of $(12.5 \mu \mathrm{g} / \mathrm{mL})$ FMSP-nanoparticles and $(100 \mu \mathrm{g} / \mathrm{mL})$ clove extracts treated cells showed a little less of DAPI stained cells (Figure 5(b)). The dosages of $50 \mu \mathrm{g} / \mathrm{mL}$ and $100 \mu \mathrm{g} / \mathrm{mL}$ FMSP-nanoparticles and $(100 \mu \mathrm{g} / \mathrm{mL})$ clove extract treated 


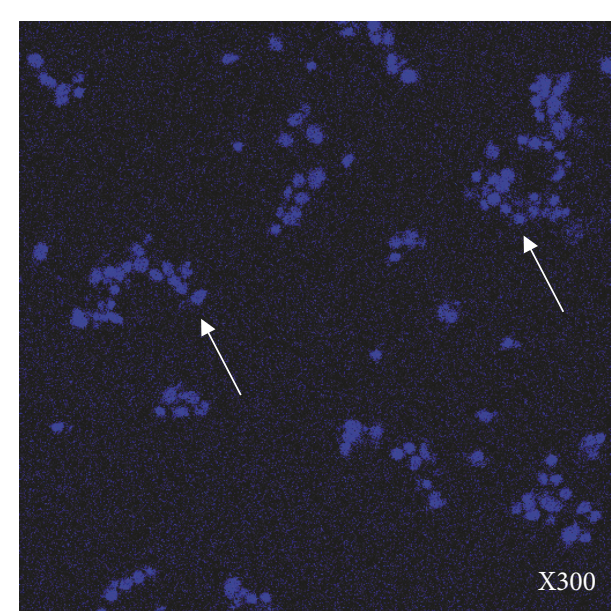

(a)

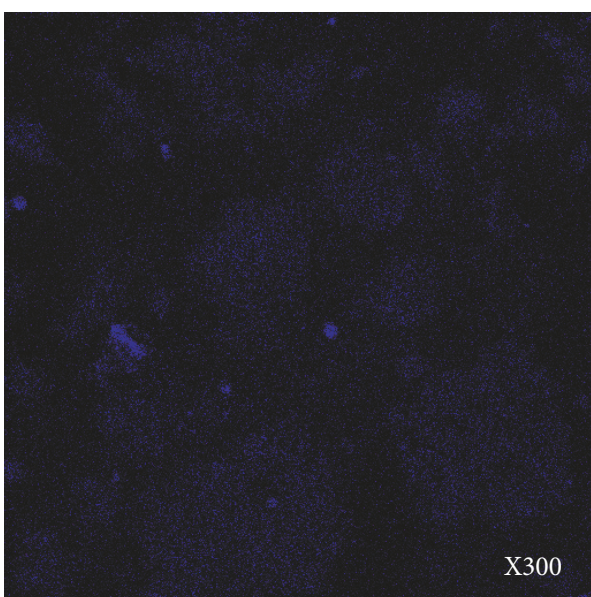

(c)

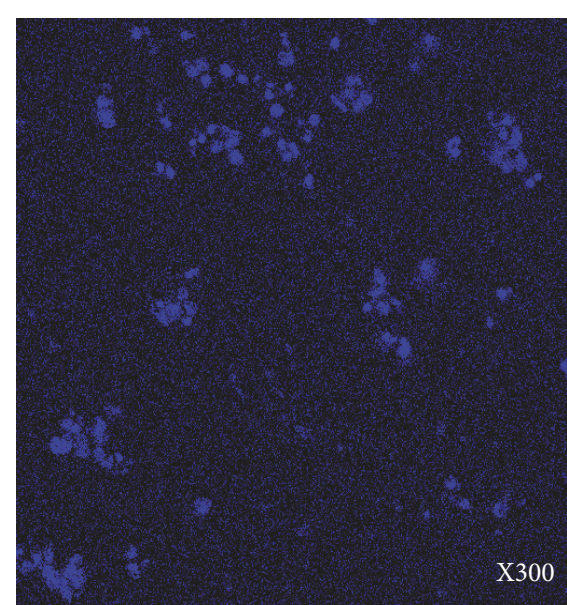

(b)

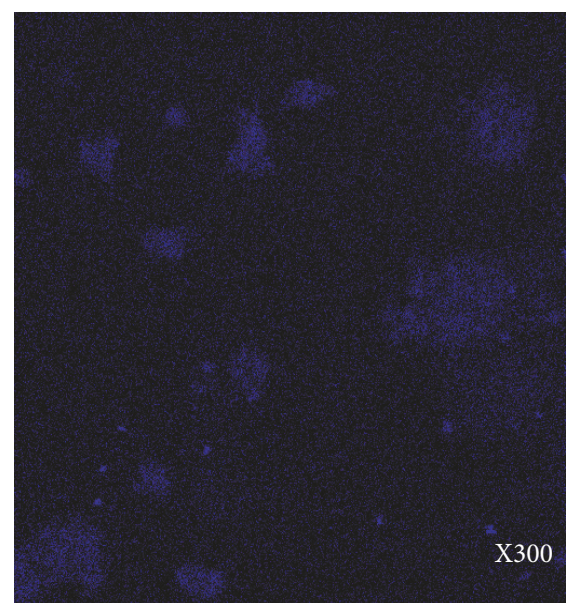

(d)

FIgURE 5: Scanning Microscopy through DAPI stained cells: the MCF-7 cells were stained with DAPI after 48 hrs of treatments. Figure (a) is control, live cells stained with blue (arrows); (b) treated with FMSP-nanoparticles $(12.5 \mu \mathrm{g} / \mathrm{mL})+$ clove extracts $(100 \mu \mathrm{g} / \mathrm{mL})$; (c) treated with FMSP-nanoparticles $(50 \mu \mathrm{g} / \mathrm{mL})+$ clove extracts $(100 \mu \mathrm{g} / \mathrm{mL})$; (d) treated with FMSP-nanoparticles $(100 \mu \mathrm{g} / \mathrm{mL})+$ clove extracts $(100 \mu \mathrm{g} / \mathrm{mL})$; $300 \mathrm{x}$ magnifications.

cells showed significant loss of staining after $48 \mathrm{hrs}$ (Figures 5(c) and 5(d)).

\section{Discussion}

We have reported that the combination of FMSPnanoparticles along with clove extracts has a profound effect in reducing the cancer cell survivability and cell proliferation. Both FMSP-nanoparticles and cloves (Syzyium aromaticum) have a wide range of pharmacological and biochemical effects, including anti-inflammatory, antihyperlipidemic, and hypoglycaemic effects [32, 33]. Interestingly, there is disparity in the effect of clove extracts on cancer cells; in one study, it was reported that an extract of clove induces apoptosis in Panc-28 cells [34], whereas, in another study, it was demonstrated that an extract of clove was unable to increase ROS production in HT-29 cells [35]. But in the current study, we have shown that treatment of clove extract in combination with FMSP-nanoparticles enhanced the cancer cell death compared to cell death when FMSP-nanoparticles and clove extracts treated separately.

The objective of our study to investigate whether an extract of clove potentiates the response of FMSPnanoparticles on the cancer cells. Our study provides further evidence that a combination of extract of clove with FMSPnanoparticles is more effective than FMSP-nanoparticles alone treated cells. There are several studies which have been reported that combining clove extracts with 5-fluorouracilcaused a synergistic effect on cancer growth inhibition [36] (Wei et al., 2012). While there is no report on the use of clove extracts to potentiate any nanoparticles responses on cancer cells, this is first report where we have demonstrated that clove extracts enhanced FMSP-nanoparticles mediated cell death in cancer cells.

Inhibition of cell growth progression in cancer cells is one of the most effective approaches for the control of tumour 


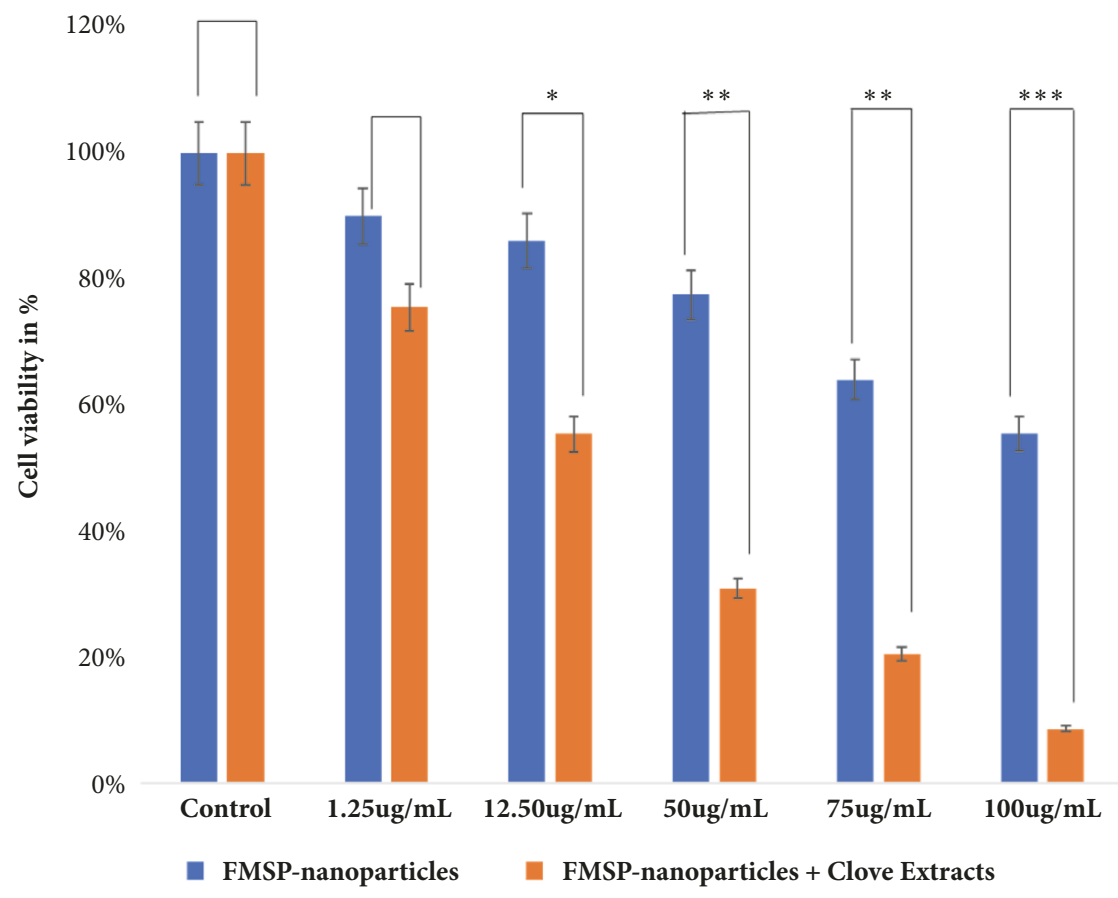

FIGURE 6: Cell viability analysis by MTT Assay. The MCF-7 cells were treated with FMSP-nanoparticles alone and with clove extracts. FMSPnanoparticles with concentrations $1.25 \mu \mathrm{g} / \mathrm{mL}, 12.50 \mu \mathrm{g} / \mathrm{mL}, 50 \mu \mathrm{g} / \mathrm{mL}, 75 \mu \mathrm{g} / \mathrm{mL}$, and $100 \mu \mathrm{g} / \mathrm{mL}$, whereas clove extracts with concentration $100 \mu \mathrm{g} / \mathrm{mL}$ were used for $48 \mathrm{hrs}$. Data are the means \pm SD of three different experiments. Differences between two treatment groups were analyzed by Student's $t$-test where ${ }^{*} \mathrm{p}<0.05,{ }^{* *} \mathrm{p}<0.01$; ${ }^{* *} \mathrm{p}<0.001$; p-values were calculated by Student's $t$-test.

growth [37]. Our finding showed that the significant decrease in the cell proliferation after $24 \mathrm{hrs}$ and further decrease after $48 \mathrm{hrs}$ posttreatment in a dose-dependent manner. It would be interesting to study the cell cycle progression after combined treatment of clove extracts with FMSPnanoparticles. Moreover, it has been previously shown that treatment of an extract of clove caused a significant increase of G0/G1 phase cells was accompanied by a decrease of cells in the S and G2/M phases, respectively [29]. While we do not know the molecular mechanism behind such strong combined effects on cancer cells, the synergistic effect of clove extracts on FMSP-nanoparticles cannot be ruled out. It would be interesting to study the cancer cell death by blocking the response of the combined effects of clove extracts and FMSPnanoparticles on cancer cells by using specific antagonists.

The size and concentration of nanoparticles play very crucial role in inducing therapeutic effects on cancer cells and variations in the concentration and sizes of nanoparticles do produce inconsistent effects. Most of the studies have used different concentrations of nanoparticles ranging from $10 \mathrm{ug} / \mathrm{ml}$ to $200 \mathrm{ug} / \mathrm{ml}$ to obtain desirable therapeutic effects [38-43]. The size of the nanoparticles is used ranged between $10 \mathrm{nM}$ and $200 \mathrm{nM}$ on the cancer cells $[38,42]$. The nanoparticles with size $100 \mathrm{~nm}$ and above do not give any desirable therapeutic effects with low concentration, whereas high concentration gives good therapeutic response but poses serious health and safety problems. In the present study, we have shown that low concentration of FMSP-nanoparticles in combination with clove extracts produced a profound impact on the cancerous cells.
Besides quantitative analysis, we were also interested to know how FMSP-nanoparticles and clove extracts induce morphological changes on cancer cells. During morphometric analysis, we found that FMSP-nanoparticles treated with clove extract caused significant nuclear fragmentation and disintegration. The nuclear fragmentation and disintegration are an indication of programmed cell death, as we have seen during quantitative analysis that there was a significant cell death after combined treatment of FMSP-nanoparticles and clove extract. Both morphometric and quantitative analyses confirmed that FMSP-nanoparticles in combination with clove extracts induced concentration-dependent effects on the cancer cells. There are several reports which demonstrated that nanoparticles such as silver nanoparticles showed a strong inhibitory effect on the growth of lung tumour cells, human tongue squamous carcinoma, human breast cancer cells, and chronic myeloid leukaemia cells (He et al., 2017) $[44,45]$. Both Trypan blue and MTT assays results confirm that FMSP-nanoparticles induced a dose-dependent cytotoxic effects on MCF-7 cells. These results confirm that FMSPnanoparticles have dose-dependent effects on the cancer cells death. We do not know the mechanism of action of FMSPnanoparticles in eliciting cancer cell death; the possibility of apoptotic pathways cannot be ruled.

\section{Conclusion}

In the present study, we have demonstrated that FMSPnanoparticles in combination with clove extracts induced 
concentration-dependent cell death of cancer cells. When FMSP-nanoparticles treated alone, the dose of $1.25 \mu \mathrm{g} / \mathrm{mL}$ decreases cell survivability to $90.03 \%$, whereas those of $12.5 \mu \mathrm{g} / \mathrm{mL}, \quad 50 \mu \mathrm{g} / \mathrm{mL}, \quad 75 \mu \mathrm{g} / \mathrm{mL}, \quad$ and $100 \mu \mathrm{g} / \mathrm{mL}$ caused decrease of cell survivability to $86.14 \%, 77.54 \%$, $64.00 \%$, and $55.40 \%$, respectively. Interestingly, when FMSP-nanoparticles were treated in combination with clove extracts, the dose of $(1.25 \mu \mathrm{g} / \mathrm{mL}+100 \mu \mathrm{g} / \mathrm{mL})$ decreased cell survivability to $75.00 \%$, whereas a dose of $12.5 \mu \mathrm{g} / \mathrm{mL}+100 \mu \mathrm{g} / \mathrm{mL}, \quad 50 \mu \mathrm{g} / \mathrm{mL}+100 \mu \mathrm{g} / \mathrm{mL}$, $75 \mu \mathrm{g} / \mathrm{mL}+100 \mu \mathrm{g} / \mathrm{mL}$, and $100 \mu \mathrm{g} / \mathrm{mL}+100 \mu \mathrm{g} / \mathrm{mL}$ caused decrease of cell survivability to $55.35 \%, 30.85 \%, 20.40 \%$, and $8.50 \%$, respectively. In the study, we have demonstrated that the combination of FMSP-nanoparticles along with clove extracts profoundly decreases the cell survivability of cancer cells in a dose-dependent manner. Finally, we suggest that the use of combination approach is the most effective way to treat cancer cells and FMSP-nanoparticles along with clove extracts hold strong hope for the patients who are suffering from cancer.

\section{Abbreviations}

\begin{tabular}{|c|c|}
\hline ROS: & Reactive oxygen species \\
\hline HT-29: & $\begin{array}{l}\text { Human colorectal } \\
\text { adenocarcinoma cell line }\end{array}$ \\
\hline MCF-7: & $\begin{array}{l}\text { MCF-7 is a breast cancer cell line. } \\
\text { MCF-7 is the acronym of Michigan } \\
\text { Cancer Foundation-7 }\end{array}$ \\
\hline $\mathrm{CO}_{2}:$ & Carbon dioxide \\
\hline DAPI: & $4^{\prime}, 6$-Diamidino-2-phenylindole \\
\hline DMSO: & Dimethyl sulfoxide \\
\hline DMEM: & $\begin{array}{l}\text { Dulbecco's Modified Eagle } \\
\text { Medium }\end{array}$ \\
\hline ELISA: & $\begin{array}{l}\text { Enzyme-linked immunosorbent } \\
\text { assay }\end{array}$ \\
\hline FBS: & Fetal bovine serum \\
\hline IU: & International Unit \\
\hline FMSP-nanoparticles: & $\begin{array}{l}\text { Fluorescent magnetic submicronic } \\
\text { polymer nanoparticles }\end{array}$ \\
\hline MNPs: & Magnetic nanoparticles \\
\hline MTT: & $\begin{array}{l}\text { 3-(4,5-dimethylthiazol-2-yl)-2,5- } \\
\text { diphenyltetrazolium } \\
\text { bromide }\end{array}$ \\
\hline $\mathrm{nm}:$ & Nanometre \\
\hline NPs: & Nanoparticles \\
\hline OD: & Optical density \\
\hline SEM: & Scanning electron microscopy \\
\hline TEM: & Transmission electron microscopy \\
\hline$\mu \mathrm{g}:$ & Microgram \\
\hline$\mu \mathrm{l}:$ & Microliter. \\
\hline
\end{tabular}

\section{Data Availability}

The data used to support the findings of this study are available from the corresponding author upon request.

\section{Conflicts of Interest}

The authors declare that they have no conflicts of interest.

\section{Authors' Contributions}

All the authors approved this manuscript for the submission.

\section{Acknowledgments}

The authors are thankful to the entire management of the Institute for Research \& Medical Consultations (IMRC), Imam Abdulrahman Bin Faisal University, Dammam, Saudi Arabia, for their support and encouragement. They thank Mr. Dionecio Jr. Bagon Dela Roca for assisting the cell culture and bioassay related work. They also thank Dr. Khaldoon M. Alsamman, Clinical Laboratory Science, College of Applied Medical Science, Imam Abdulrahman Bin Faisal University, Dammam, Saudi Arabia, for providing MCF-7 cell line. They thank Professor Hamid Abdelhamid Eliassari, University of Lyon, F-69622 Lyon, France, University Lyon 1, Villeurbanne, CNRS, UMR 5007, LAGEP-CPE, 43 Bd. 11 Novembre 1918, F69622 Villeurbanne, France, for providing the nanoparticles. Financial support was received from Deanship of Scientific Research, Imam Abdulrahman Bin Faisal University, Dammam, Saudi Arabia (Grant no. 2018-004-IRMC).

\section{References}

[1] J. Ferlay, C. Héry, P. Autier, and R. Sankaranarayanan, "Global burden of breast cancer," Breast Cancer Epidemiology, pp. 1-19, 2010.

[2] L. Kelland, "The resurgence of platinum-based cancer chemotherapy," Nature Reviews Cancer, vol. 7, no. 8, pp. 573-584, 2007

[3] F. C. Hamdy, J. L. Donovan, J. A. Lane et al., "10-Year outcomes after monitoring, surgery, or radiotherapy for localized prostate cancer," The New England Journal of Medicine, vol. 375, no. 15, pp. 1415-1424, 2016.

[4] A. Espinosa, R. Di Corato, J. Kolosnjaj-Tabi, P. Flaud, T. Pellegrino, and C. Wilhelm, "Duality of iron oxide nanoparticles in cancer therapy: amplification of heating efficiency by magnetic hyperthermia and photothermal bimodal treatment," ACS Nano, vol. 10, no. 2, pp. 2436-2446, 2016.

[5] M. Rezaee, R. K. Oskuee, H. Nassirli, and B. Malaekeh-Nikouei, "Progress in the development of lipopolyplexes as efficient nonviral gene delivery systems," Journal of Controlled Release, vol. 236, pp. 1-14, 2016.

[6] C. Maccalli and R. De Maria, "Cancer stem cells: perspectives for therapeutic targeting," Cancer Immunology, Immunotherapy, vol. 64, no. 1, pp. 91-97, 2015.

[7] Y. Inoue, T. Iwata, Y. Okugawa et al., "Prognostic significance of a systemic inflammatory response in patients undergoing multimodality therapy for advanced colorectal cancer," Oncology, vol. 84, no. 2, pp. 100-107, 2012.

[8] F. Dimou, H. Sineshaw, A. D. Parmar, N. P. Tamirisa, A. Jemal, and T. S. Riall, "Trends in receipt and timing of multimodality therapy in early-stage pancreatic cancer," Journal of Gastrointestinal Surgery, vol. 20, no. 1, pp. 93-103, 2016.

[9] D. Bobo, K. J. Robinson, J. Islam, K. J. Thurecht, and S. R. Corrie, "Nanoparticle-based medicines: a review of FDA-approved materials and clinical trials to date," Pharmaceutical Research, vol. 33, no. 10, pp. 2373-2387, 2016.

[10] E. Afrimzon, A. Deutsch, Y. Shafran et al., "Intracellular esterase activity in living cells may distinguish between metastatic and 
tumor-free lymph nodes," Clinical \& Experimental Metastasis, vol. 25, no. 3, pp. 213-224, 2008.

[11] V. Castranova, "Overview of current toxicological knowledge of engineered nanoparticles," Journal of Occupational and Environmental Medicine, vol. 53, no. 6, pp. S14-S17, 2011.

[12] S. Aftab, A. Shah, A. Nadhman et al., "Nanomedicine: an effective tool in cancer therapy," International Journal of Pharmaceutics, vol. 540, no. 1-2, pp. 132-149, 2018.

[13] E. Gottlieb, S. M. Armour, M. H. Harris, and C. B. Thompson, "Mitochondrial membrane potential regulates matrix configuration and cytochrome c release during apoptosis," Cell Death \& Differentiation, vol. 10, no. 6, pp. 709-717, 2003.

[14] A. Wood, J. Schneider, and A. Shilatifard, "Cross-talking histones: implications for the regulation of gene expression and DNA repair," The International Journal of Biochemistry \& Cell Biology, vol. 83, no. 4, pp. 460-467, 2005.

[15] K. S. M. Smalley and M. Herlyn, "Towards the targeted therapy of melanoma," Mini-Reviews in Medicinal Chemistry, vol. 6, no. 4, pp. 387-393, 2006.

[16] K. Unfried, C. Albrecht, L.-O. Klotz, A. von Mikecz, S. GretherBeck, and R. P. F. Schins, "Cellular responses to nanoparticles: target structures and mechanisms," Nanotoxicology, vol. 1, no. 1, pp. 52-71, 2007.

[17] C. Hanley, J. Layne, A. Punnoose et al., "Preferential killing of cancer cells and activated human $\mathrm{T}$ cells using $\mathrm{ZnO}$ nanoparticles," Nanotechnology, vol. 19, no. 29, Article ID 295103, 2008.

[18] S. Turcotte, D. A. Chan, P. D. Sutphin, M. P. Hay, W. A. Denny, and A. J. Giaccia, "A molecule targeting VHL-deficient renal cell carcinoma that induces autophagy," Cancer Cell, vol. 14, no. 1, pp. 90-102, 2008.

[19] J. W. Rasmussen, E. Martinez, P. Louka, and D. G. Wingett, "Zinc oxide nanoparticles for selective destruction of tumor cells and potential for drug delivery applications," Expert Opinion on Drug Delivery, vol. 7, no. 9, pp. 1063-1077, 2010.

[20] R. Mathew and E. White, "Autophagy in tumorigenesis and energy metabolism: Friend by day, foe by night," Current Opinion in Genetics \& Development, vol. 21, no. 1, pp. 113-119, 2011.

[21] X. Wang, W. Wang, L. Li, G. Perry, H. G. Lee, and X. Zhu, "Oxidative stress and mitochondrial dysfunction in Alzheimer's disease," Biochimica et Biophysica Acta, vol. 1842, no. 8, pp. 1240-1247, 2014.

[22] R. Pati, I. Das, R. K. Mehta, R. Sahu, and A. Sonawane, "Zincoxide nanoparticles exhibit genotoxic, clastogenic, cytotoxic and actin depolymerization effects by inducing oxidative stress responses in macrophages and adult mice," Toxicological Sciences, vol. 150, no. 2, pp. 454-472, 2016.

[23] H. Jiang, X. Shi, X. Yu, X. He, Y. An, and H. Lu, "Hyaluronidase enzyme-responsive targeted nanoparticles for effective delivery of 5-fluorouracil in colon cancer," Pharmaceutical Research, vol. 35, no. 4, 2018.

[24] H. V. K. Diyabalanage, M. L. Granda, and J. M. Hooker, "Combination therapy: histone deacetylase inhibitors and platinumbased chemotherapeutics for cancer," Cancer Letters, vol. 329, no. 1, pp. 1-8, 2013.

[25] X.-F. Zhang, Q. Yan, W. Shen, and S. Gurunathan, "Trichostatin A enhances the apoptotic potential of palladium nanoparticles in human cervical cancer cells," International Journal of Molecular Sciences, vol. 17, no. 8, article 1354, 2016.

[26] M. W. Chao, M. J. Lai, J. P. Liou et al., "The synergic effect of vincristine and vorinostat in leukemia in vitro and in vivo," Journal of Hematology \& Oncology, vol. 8, no. 82, 2015.
[27] K. Venugopal, H. A. Rather, K. Rajagopal et al., "Synthesis of silver nanoparticles (Ag NPs) for anticancer activities (MCF 7 breast and A549 lung cell lines) of the crude extract of Syzygium aromaticum," Journal of Photochemistry and Photobiology B: Biology, vol. 167, pp. 282-289, 2017.

[28] V. Elsyana, M. Bintang, and B. P. Priosoeryanto, "Cytotoxicity and antiproliferative activity assay of clove mistletoe (Dendrophthoe pentandra (L.) Miq.) leaves extracts," Advances in Pharmacological Sciences, vol. 2016, Article ID 3242698, 6 pages, 2016.

[29] H. Liu, J. C. Schmitz, J. Wei et al., "Clove extract inhibits tumor growth and promotes cell cycle arrest and apoptosis," Oncology Research: Featuring Preclinical and Clinical Cancer Therapeutics, vol. 21, no. 5, pp. 247-259, 2014.

[30] V. Dwivedil, R. Shrivastaval, S. Hussain, C. Ganguly, and M. Bharadwaj, "Comparative anticancer potential of clove (Syzygium aromaticum) — an indian spice-against cancer cell lines of various anatomical origin," Asian Pacific Journal of Cancer Prevention, vol. 12, no. 8, pp. 1989-1993, 2011.

[31] M. Lansalot, M. Sabor, A. Elaissari, and C. Pichot, "Elaboration of fluorescent and highly magnetic submicronic polymer particles via a stepwise heterocoagulation process," Colloid and Polymer Science, vol. 283, no. 12, pp. 1267-1277, 2005.

[32] A. Hussain, K. Brahmbhatt, A. Priyani, M. Ahmed, T. A. Rizvi, and C. Sharma, "Eugenol enhances the chemotherapeutic potential of gemcitabine and induces anticarcinogenic and antiinflammatory activity in human cervical cancer cells," Cancer Biotherapy and Radiopharmaceuticals, vol. 26, no. 5, pp. 519-527, 2011.

[33] V. Amico, V. Barresi, R. Chillemi et al., "Bioassay-guided isolation of antiproliferative compounds from grape (Vitis vinifera) stems," Natural Product Communications, vol. 4, no. 1, pp. 27-34, 2009.

[34] J. Wei, M. Liu, H. Liu et al., "Oleanolic acid arrests cell cycle and induces apoptosis via ROS-mediated mitochondrial depolarization and lysosomal membrane permeabilization in human pancreatic cancer cells," Journal of Applied Toxicology, vol. 33, no. 8, pp. 756-765, 2013.

[35] E. M. Juan, J. M. Planas, V. Ruiz-Gutierrez, H. Daniel, and U. Wenzel, "Antiproliferative and apoptosis-inducing effects of maslinic and oleanolic acids, two pentacyclic triterpenes from olives, on HT-29 colon cancer cells," British Journal of Nutrition, vol. 100, no. 1, pp. 36-43, 2008.

[36] S. Prasad, V. R. Yadav, B. Sung et al., "Ursolic acid inhibits growth and metastasis of human colorectal cancer in an orthotopic nude mouse model by targeting multiple cell signaling pathways: Chemosensitization with capecitabine," Clinical Cancer Research, vol. 18, no. 18, pp. 4942-4953, 2012.

[37] W. Nam, J. Tak, J.-K. Ryu et al., "Effects of artemisinin and its derivatives on growth inhibition and apoptosis of oral cancer cells," Head \& Neck, vol. 29, no. 4, pp. 335-340, 2007.

[38] E. I. Kandil, S. M. El-sonbaty, F. S. Moawed, and O. M. Khedr, "Anticancer redox activity of gallium nanoparticles accompanied with low dose of gamma radiation in female mice," Tumor Biology, vol. 40, no. 3, 2018.

[39] Z. Fakhroueian, R. Vahabpour, M. Assmar et al., "ZnO Q-dots as a potent therapeutic nanomedicine for in vitro cytotoxicity evaluation of mouth KB44, breast MCF7, colon HT29 and HeLa cancer cell lines, mouse ear swelling tests in vivo and its side effects using the animal model," Artificial Cells, Nanomedicine and Biotechnology, pp. 1-16, 2018. 
[40] M. H. Akanda, R. Rai, I. J. Slipper et al., "Delivery of retinoic acid to LNCap human prostate cancer cells using solid lipid nanoparticles," International Journal of Pharmaceutics, vol. 493, no. 1-2, pp. 161-171, 2015.

[41] S. Mazumdar, K. S. Italiya, S. Sharma, D. Chitkara, and A. Mittal, "Effective cellular internalization, cell cycle arrest and improved pharmacokinetics of Tamoxifen by cholesterol based lipopolymeric nanoparticles," International Journal of Pharmaceutics, vol. 543, no. 1-2, pp. 96-106, 2018.

[42] V. R. Netala, S. Bukke, L. Domdi et al., "Biogenesis of silver nanoparticles using leaf extract of Indigofera hirsuta L. and their potential biomedical applications (3-in-1 system)," Artificial Cells, Nanomedicine and Biotechnology, pp. 1-11, 2018.

[43] P. Kumar, A. K. Singh, V. Raj et al., "Poly(Lactic-co-glycolic acid)-loaded nanoparticles of betulinic acid for improved treatment of hepatic cancer: Characterization, in vitro and in vivo evaluations," International Journal of Nanomedicine, vol. 13, pp. 975-990, 2018.

[44] A. Dziedzic, R. Kubina, R. J. Bułdak, M. Skonieczna, and K. Cholewa, "Silver nanoparticles exhibit the dose-dependent antiproliferative effect against human squamous carcinoma cells attenuated in the presence of berberine," Molecules, vol. 21, no. 3, article 365, 2016.

[45] E. Locatelli, M. Naddaka, C. Uboldi et al., "Targeted delivery of silver nanoparticles and alisertib: in vitro and in vivo synergistic effect against glioblastoma," Nanomedicine, vol. 9, no. 6, pp. 839-849, 2014. 


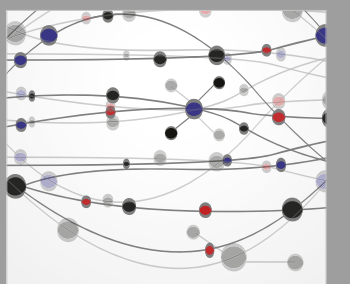

The Scientific World Journal
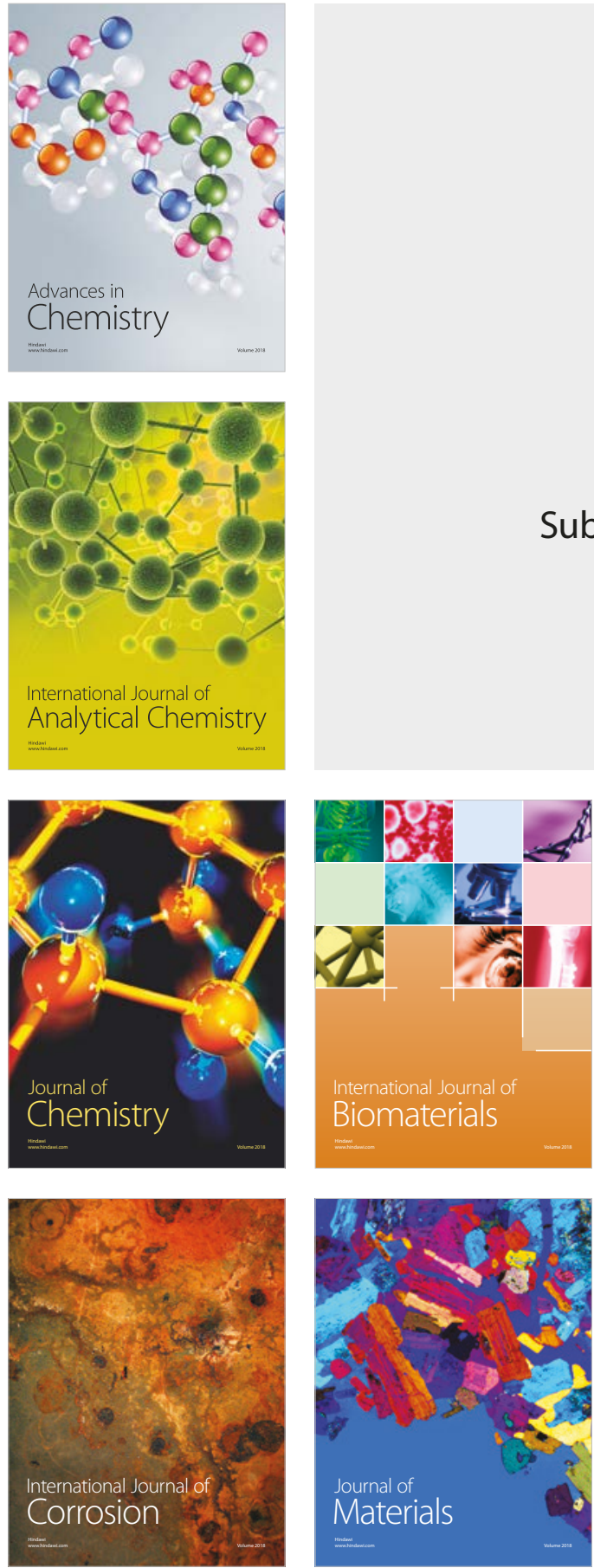

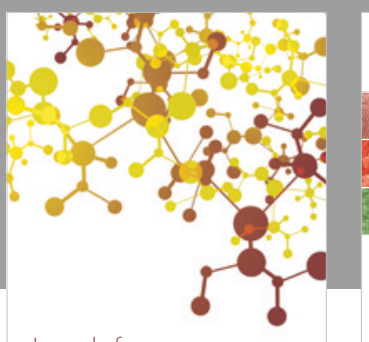

Journal of

Applied Chemistry
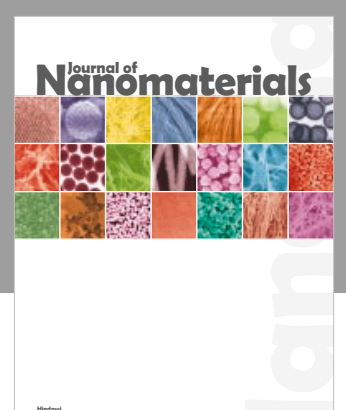

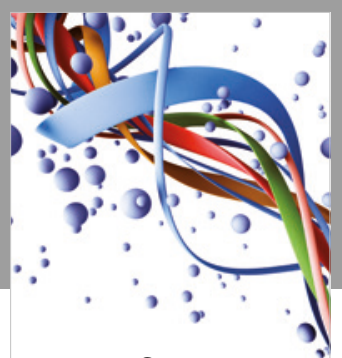

Scientifica

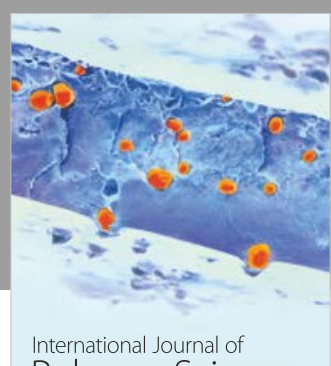

Polymer Science

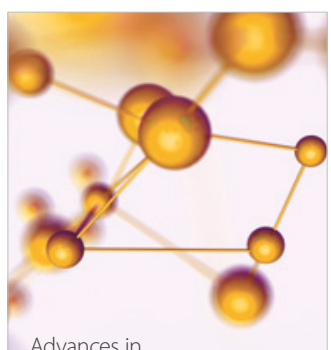

Physical Chemistry
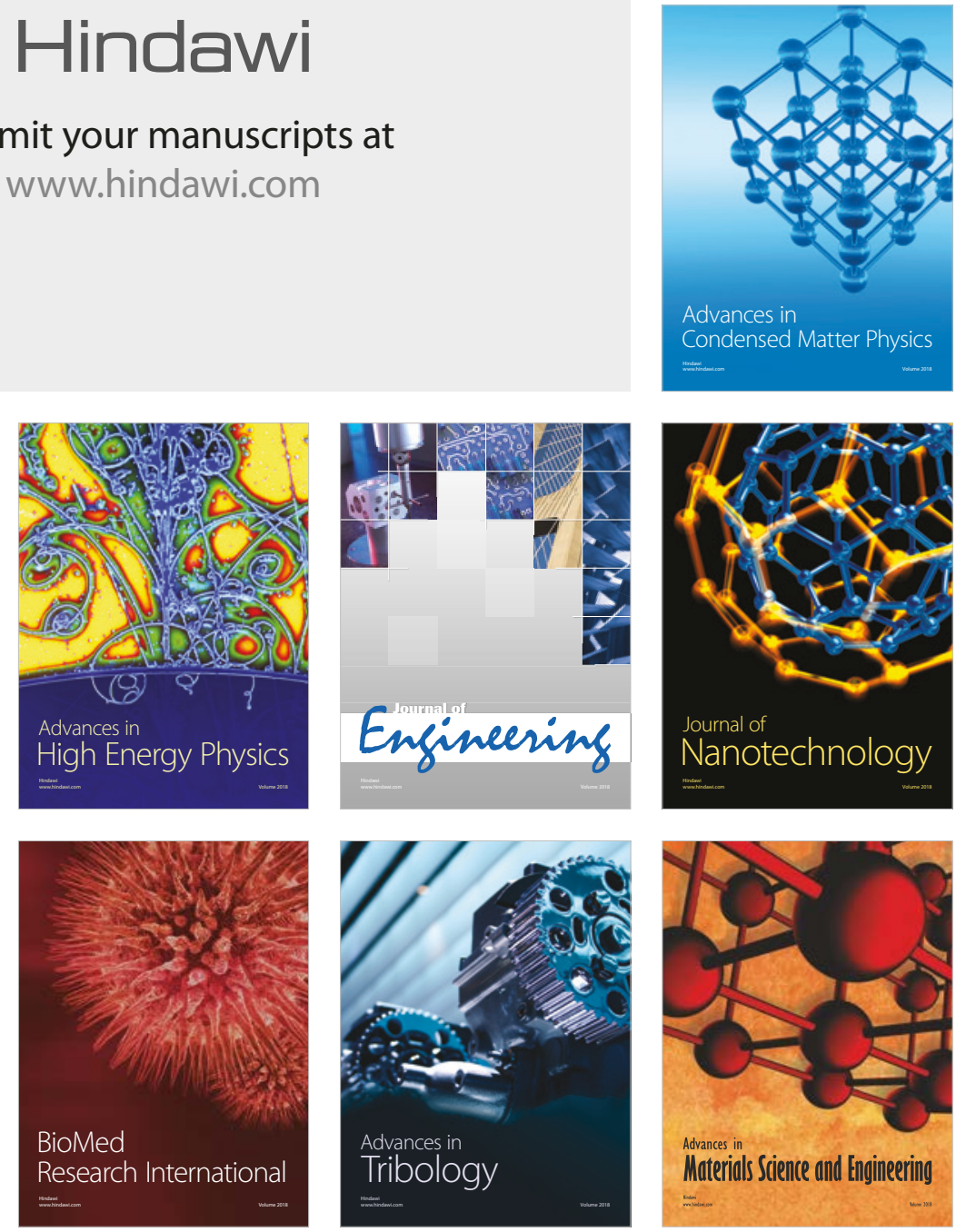